Article

\title{
Ranking EU Countries According to Their Level of Success in Achieving the Objectives of the Sustainable Development Strategy
}

\author{
Svjetlana Janković Šoja *, Ana Anokić ${ }^{\dagger}$, Dana Bucalo Jelić ${ }^{\dagger}$ and Radojka Maletić $^{\dagger}$ \\ Department of Statistics, Faculty of Agriculture, University of Belgrade, Nemanjina 6, Belgrade 11000, Serbia; \\ anokicana@agrif.bg.ac.rs (A.A.); bucalo@agrif.bg.ac.rs (D.B.J.); maletic@agrif.bg.ac.rs (R.M.) \\ * Correspondence: svjetlanajs@agrif.bg.ac.rs; Tel.: +381-60-554-9604 \\ + The authors contributed equally to this work.
}

Academic Editors: Nicholas Ashford and Marc A. Rosen

Received: 30 December 2015; Accepted: 23 March 2016; Published: 28 March 2016

\begin{abstract}
Sustainable development as a concept, is extremely important both at national and international levels. To achieve the goals of sustainable development, international cooperation among countries is of vital importance because no one nation can accomplish these goals independently. In order to implement the sustainable development strategy, first discussed in 1992 at the UN Conference of Environment and Development, the indicators of sustainable development first had to be defined. Considering that the first set of indicators was defined by the Commission on Sustainable Development (CSD), they were entitled CSD indicators. The smaller set of CSD indicators in the European Union countries (EU-28) is observed in this study. These indicators cover three aspects of sustainable development: economic, social and environmental. The goal of this study is to rank EU countries according to the level that they were able to achieve the objectives of their respective sustainable development strategies individually, according to the 2013 database. The appropriate statistical I-distance method was used for this purpose. In the first step, the significant indicators are distinguished and ranked according to the quantity and importance of the information they provide for specific research. Subsequently, this method then converts the indicators into a single measure that reflects the level at which each country has achieved the goal.
\end{abstract}

Keywords: sustainable development; Commission on Sustainable Development (CSD) indicators; I-distance method; ranking; European Union (EU-28) countries

\section{Introduction}

Recently, the concept of sustainable development has become a central topic of interest for scientists from various areas of research. The issue of sustainable development raises the following question: how do we provide for the survival and progress of humankind, whilst at the same time ensuring that we do not jeopardise future generations? [1]. This is a significant issue both at national and international levels [2] due to the increasing amount of pressure caused by a growing global population on one end, and limited natural resources and food supplies on the other. Today's standard of living has increased significantly in comparison to the past but maintaining this standard has had a negative effect on the environment. This is the reason why it is crucial that we find balance between these opposing sides, i.e., progress which cannot be stopped and the constant dwindling of our natural resources. For this reason, it is necessary to continuously monitor indicators within the field of sustainable development that enable us to observe each individual situation per country.

The first significant step taken in terms of sustainable development was the United Nations Conference on Environment and Development, which took place in Rio de Janeiro in 1992. The 
following year the Commission on Sustainable Development (CSD) was founded and its aim was to supervise the implementation of the decisions taken. For this purpose, in 1995, the first set of 134 CSD indicators for the successful evaluation of measures and activities regarding the implementation of sustainable development strategies were defined. At this time, the first set of indicators was tested on several occasions, reviewed and then adapted to the Millennium Development Goals. Today, the current set of indicators includes 96 CSD indicators, 50 of which belong to the basic set of indicators [3].

Although, the disestablishment of the Commission on Sustainable Development began in December 2012, the General Assembly of the United Nations recommended that the Commission on Sustainable Development hold its final session on 20 September 2013 [4]. A few days later, the Commission on Sustainable Development turned over its functions relating to the implementation of Agenda 21 to the new High-level Political Forum on Sustainable Development. On this occasion, it was concluded that the Commission on Sustainable Development had contributed greatly to the implementation of the objectives of sustainable development, especially in terms of the process of forming a set of indicators. This process continued over a period of 10 years and was not an easy task, according to Bedrich Moldan, Director of Charles University, Prague, and Chair of the Commission at its ninth session. "He remarked that currently it had become clear that those indicators were very useful.... He concluded that an analysis of the Commission's impacts over 20 years and its legacy should help to bolster the success of the High-level Political Forum on Sustainable Development" [5]. Having in mind all of the above and the fact that "...the Commission on Sustainable Development has been serving as the high-level body responsible for sustainable development within the United Nations system and as a forum for the consideration of issues related to the integration of the three dimensions of sustainable development,..." [4], the authors of this paper took the decision to conduct their research with these indicators, which had remained relevant for many years. Additionally, an additional set of indicators that was formed by the UN, which sets up the basis for monitoring the implementation of sustainable development strategies, could not be found by the authors of this study.

CSD indicators in European Union countries are considered in this paper. However, this research involves a significantly smaller number of indicators. The reason for this is the indicators selection process, which will be explained in the second part of this paper, Materials and Methods, and data availability in all EU countries was taken into consideration. Specific indicators that are not typical for all countries have not been taken into consideration. Thereby, special attention was paid to include indicators from all areas of the sustainable development strategy: economic, social and environmental indicators.

The aim of this research is to use appropriate statistical procedures to rank EU countries (EU-28) according to the level of achievement of sustainable development strategy objectives and thus to identify EU countries which lag behind in this regard. Considering the fact that this study includes a large number of indicators, the statistical I-distance method was chosen, which enables the analysis of a large number of variables.

Numerous studies have recently dealt with the socio-economic development of European Union [6,7] or Middle East and North Africa (MENA) countries [8] using the I-distance method. Furthermore, the I-distance method was used to rank EU countries (EU-27) according to the status of their health care systems [9] and the world's universities [10]. The I-distance method is used in agricultural economics to rank municipalities in the Republic of Serbia according to the level of small and medium-sized entrepreneurial development in agricultural business [11], or to rank municipalities in Vojvodina according to their operational efficiency [12], and also to rank the districts of the Republic of Serbia [13] according to the same criteria.

Many authors are attempting to find an integrated methodological framework for the assessment of a sustainable development system [14,15], which is extremely complex as it includes the following three inseparable fields: economy, society and the environment. They are also trying to define and rank those indicators most important to sustainable development strategy implementation [16]. Considering all this, the advantage of the I-distance method is obvious; it separates significant indicators in the first 
step and ranks them according to the quantity and importance of the information provided for specific research. Subsequently, it converts these indicators into a single measure that reflects the level of the goals achieved.

\section{Materials and Methods}

The study includes EU countries (EU-28) ranked according to the achieved objectives of the 2013 sustainable development strategy. The 2013 calendar year was chosen as this is the last year with available data, related to all observed indicators and all countries. The indicators that measure sustainable development are chosen according to the instructions of the Commission on Sustainable Development (CSD), and are prepared by the United Nations Department of Economic and Social Affairs. This Department is a vital interface between global policies in economic, social and environmental spheres and national action [3]. This fact implies the significance of the instructions themselves. These instructions include 96 sustainable development indicators which have been divided into fourteen themes: poverty, governance, health, education, demographics, natural hazards, atmosphere, land, oceans, seas and coasts, freshwater, biodiversity, economic development, global economic partnership, consumption and production patterns. Each theme has its own sub-themes. There are a total of 44 sub-themes, in which the indicators are divided into two categories: core indicators and other indicators. Only those indicators, which belong to the category of core indicators and the themes for which data was available for all countries, are included in the research. Indicators which belong to the following themes: governance, natural hazards, oceans, seas and coasts, freshwater, biodiversity, global economic partnership, consumption and production patterns were not included because the data were not available. Of course, this does not mean that the importance of these themes is diminished in any way, nor that the authors had any intention of reducing their level of importance. On the contrary, in recent years, a great deal of attention has been placed on the connection between themes concerning the environment and development. Economic growth is an important determinant of the environmental outlook. "The sheer scale of economic activity can lead to impacts on the environment that accumulate over time and can lead to large scale changes in the quality of the environment" [17]. For example, themes such as climate change, biodiversity loss, water scarcity and the impacts of pollution and hazardous chemicals on health are noted as "red light" issues by the Organisation for Economic Co-operation and Development (OECD) [17,18]. This means that they require urgent solutions and that it is necessary to implement an environmental policy at a global level. Otherwise, the expected scenario for the planet is terrifying. Global emissions of greenhouse gases will continue to be on the rise, which will cause both global temperatures to rise as well as the frequency with which natural disasters (droughts, storms, and floods) occur. Such climatic conditions, along with infrastructure and agriculture expansion (for the production of food and biofuel) will lead to the loss of wildlife habitats, and thus the extinction of certain animal and plant species. This in turn will lead to a dire situation relating to water scarcity. Air pollution will increase, which will directly affect public health.

It was for these reasons that a set of 20 indicators was formed in order to cover as many topics of sustainable development as was possible. Additionally, previous research on the topic of socio-economic development and prosperity in the country was taken into account while choosing the indicators [6-8]. The statistical I-distance method is applied to the elected indicators (all 20 of them), which have been chosen to determine the concept of sustainable development. The indicators are taken from World Bank Data [19] and Eurostat websites [20].

The statistical I-distance method is the metrics in an n-dimensional space [21], which enables ranking of countries on the basis of a larger number of indicators according to the development level in any field of economy and society. "The common case with different ranking methods is that their bias and subjectivity can affect the measurements and evaluation to a great extent. This problem can be somewhat overcome by the use of the I-distance method, ..., which has recently made a significant 
breakthrough" [7]. The advantage of this method is its ability to synthesise a large number of indicators into one numerical value [21], which will further define the entity's rank.

This method is primarily applied to rank countries according to economic development level on the basis of far fewer indicators $[22,23]$ than the number of indicators used today. The reason for this is quite simple, modern computer technologies and adequate statistical packages provide solutions for a highly dimensional input data matrix.

For a selected set of variables $X^{T}=\left(X_{1}, X_{2}, \ldots, X_{k}\right)$ chosen to characterise the entities, the I-squared distance between the two entities $e_{r}=\left(x_{1 r}, x_{2 r}, \ldots, x_{k r}\right)$ and $e_{s}=\left(x_{1 s}, x_{2 s}, \ldots, x_{k s}\right)$ is defined as [24]:

$$
D^{2}(r, s)=\sum_{i=1}^{k} \frac{d_{i}^{2}(r, s)}{\sigma_{i}^{2}} \prod_{j=1}^{i-1}\left(1-r_{j i .12 \ldots j-1}^{2}\right)
$$

where:

$$
d_{i}(r, s)=x_{i r}-x_{i}^{-}, i=1,2, \ldots, k
$$

represents a discriminatory effect of the indicator $X_{i}$ of the observed country and the fictional unit $X_{i}^{-}$, which is, in this case, defined by the minimum values for each observed indicator, where $\sigma_{i}$ is the standard deviation of indicator $X_{i}$, and $r_{j i .12 \ldots j-1}$ is a partial coefficient of the correlation between indicators $X_{i}$ and $X_{j}$ [24]. Due to the definition of a fictional unit, the country with the highest value of I-squared distance achieved the best results in the implementation of the sustainable development strategy. A fictional unit can also be defined with the minimal and the average values of the indicators.

In practice I-squared distance is often used to avoid negative partial coefficients of the correlation. A negative sign can be the result of opposite direction indicators [25]. It is for this reason that, in this paper, ranking was conducted by using the I-squared distance method.

The construction of the I-distance method has the following logic: the most significant indicator $\left(X_{1}\right)$, which is constructed to carry most of the information for specific research is chosen and its discriminatory effect is computed. Then, the next significant indicator $\left(X_{2}\right)$ whose discriminatory effect is not included in the previous indicator is involved in the analysis. The analysis continues until all observed indicators are included.

\section{Results and Discussion}

CSD indicators are divided according to their themes as proposed by the UN Department of Economic and Social Affairs [3]. CSD indicator themes and indicators which are included in this research are presented in Table 1.

The procedure which is used to calculate the I-squared distance values by iterations is described in the research performed by Milenkovic et al. [8]. According to them, the procedure is as follows: for the purpose of ranking European Union countries (EU-28), first, the I-squared distance method has been applied to the CSD indicators from Table 1. The obtained results have further been improved by calculating the correlation coefficient for each indicator with the obtained I-squared distance values. This procedure distinguishes the indicators that are most important for the phenomena the research refers to, but it also orders indicators according to the quantity of information they provide for specific research. The results gained from the CSD indicators are shown in Table 2. These results have been confirmed after seven iterations and they have been accepted as the most conclusive. Confirmation of the best result is the appearance of the result in two successive iterations. 
Table 1. CSD indicators included in the research.

\begin{tabular}{|c|c|c|}
\hline CSD Indicator Themes & CSD indicators & Source \\
\hline 1. Poverty & $\begin{array}{l}\text { 1.1 People at risk of poverty or social exclusion ( } \% \text { of total population) } \\
\text { 1.2 Improved sanitation facilities (\% of population with access) } \\
\text { 1.3 Improved water source (\% of population with access) }\end{array}$ & $\begin{array}{l}\text { Eurostat } \\
\text { The World Bank } \\
\text { The World Bank }\end{array}$ \\
\hline 2. Health & $\begin{array}{l}\text { 2.1 Life expectancy at birth, total (years) } \\
\text { 2.2 Mortality rate, under-5 (per 1,000 live births) } \\
\text { 2.3 Immunisation, DPT (\% of children ages } 12-23 \text { months) } \\
\text { 2.4 Immunisation, measles (\% of children ages } 12-23 \text { months) }\end{array}$ & $\begin{array}{l}\text { The World Bank } \\
\text { The World Bank } \\
\text { The World Bank } \\
\text { The World Bank }\end{array}$ \\
\hline 3. Education & $\begin{array}{l}\text { 3.1 Early dropouts-education and training (\% of the population aged } 18-24 \\
\text { with a lower secondary education at most) } \\
\text { 3.2 Lifelong learning (\% of the persons aged } 25-64 \text { who stated that they } \\
\text { received education or training in the last } 4 \text { weeks) } \\
\text { 3.3 Tertiary educational attainment age group } 30-34 \text { (\% of the population } \\
\text { aged } 30-34 \text { who have successfully completed tertiary studies ) }\end{array}$ & $\begin{array}{l}\text { Eurostat } \\
\text { Eurostat }\end{array}$ \\
\hline 4. Demographics & 4.1 Population growth (annual \%) & The World Bank \\
\hline 5. Atmosphere & $\begin{array}{l}5.1 \text { PM } 2.5 \text { air pollution, population exposed to levels exceeding WHO } \\
\text { guideline value (\% of total) } \\
5.2 \text { Greenhouse gas emissions (in } \mathrm{CO}_{2} \text { equivalent) }\end{array}$ & $\begin{array}{c}\text { The World Bank } \\
\text { Eurostat }\end{array}$ \\
\hline 6. Land & 6.1 Forest area (\% of land area) & The World Bank \\
\hline 7. Economic Development & $\begin{array}{l}\text { 7.1 GDP per capita, PPP (current international \$) } \\
\text { 7.2 Employment to population ratio, } 15+\text {, total }(\%) \\
\text { 7.3 Internet users (per } 100 \text { people) } \\
\text { 7.4 Landline subscriptions (per } 100 \text { people) } \\
\text { 7.5 Mobile telephone subscriptions (per } 100 \text { people) } \\
\text { 7.6 Research and development expenditure (\% of GDP) }\end{array}$ & $\begin{array}{l}\text { The World Bank } \\
\text { The World Bank } \\
\text { The World Bank } \\
\text { The World Bank } \\
\text { The World Bank } \\
\text { Eurostat }\end{array}$ \\
\hline
\end{tabular}

Table 2. Coefficient of the correlation between the CSD indicators and I-squared distance.

\begin{tabular}{lc}
\hline \multicolumn{1}{c}{ Indicators } & $\mathbf{R}$ \\
\hline GDP per capita, PPP (current international \$) & $0.896^{* *}$ \\
Mortality rate, under-5 (per 1000 live births) & $0.859^{* *}$ \\
Population growth (annual \%) & $0.804^{* *}$ \\
Internet users (per 100 people) & $0.761^{* *}$ \\
People at risk of poverty or social exclusion (\%) & $0.717^{* *}$ \\
Life expectancy at birth, total (years) & $0.697^{* *}$ \\
Lifelong learning (\%) & $0.686^{* *}$ \\
Research and development expenditure (\% of GDP) & $0.588^{* *}$ \\
Improved sanitation facilities (\%) & $0.512^{* *}$ \\
Tertiary educational attainment age group 30-34 (\%) & $0.473^{*}$ \\
Employment to population ratio, 15+, total (\%) & $0.424^{*}$ \\
Landline subscriptions (per 100 people) & $0.403^{*}$ \\
Greenhouse gas emissions (in CO equivalent) & $0.394^{*}$ \\
Improved water source (\% of population with access) & 0.345 \\
PM 2.5 air pollution (\% of total) & 0.266 \\
$\quad$ Immunisation, DPT (\% of children ages 12-23 months) & 0.235 \\
$\quad$ Education and training dropouts (\%) & 0.190 \\
$\quad$ Forest area (\% of land area) & 0.155 \\
Mobile telephone subscriptions (per 100 people) & 0.094 \\
\hline
\end{tabular}

$$
{ }^{* *} p<0.01 ; * p<0.05 \text {. Source: Authors' own work. }
$$

As is demonstrated in Table 2, the first 13 indicators are statistically significant $(p<0.05)$. Among them, the GDP per capita stands out as the most significant indicator with $r=0.896(p<0.01)$. The obtained result is in concordance with the research in the field of socio-economic development and the welfare of the countries in which GDP played an important role [26-29]. However, in some research, GDP per capita was not ranked among the first five indicators [8], although it is statistically very 
significant. The authors of this research refer to the Davidson hypothesis [30] that the GNP (or GDP) per capita cannot be considered as the only and crucial indicator of a country's performance, as it does not capture the overall well-being of its populations. On the other hand, "...the level of GDP in a country is viewed as its ability to provide its inhabitants with proper opportunities to enjoy good economic, social, and environmental conditions of life" [31]. The authors further point out that increasing the GDP per capita leads to an improvement of the population standard which means better health care services, secure livelihoods, access to better education, better working conditions, a healthy and sustainable environment, etc., and these are all present within themes of sustainable development. The second indicator according to its importance is Mortality rate (under five years of age) with $r=0.859(p<0.01)$ and it belongs to the group of indicators that refer to public health. The same result was obtained by Milenković et al. [8] in their study of the socio-economic development of MENA countries. The authors researching the development of health care systems have pointed out that mortality rate is a very important indicator of the health status of a country [32] and it further defines its prosperity. The indicator Internet users is ranked among the more significant indicators with $r=0.761(p<0.01)$, which is not surprising considering the fact that recently many papers underline the importance of information and communication technologies (ICTs) in the economic development and prosperity of a country $[8,33,34]$. The last seven indicators are not statistically significant, although their importance for sustainable development should not be ignored. For example, the indicator which represents the percentage of land covered by forests is important because forests play an important role in air purification. Furthermore, the importance of indicators which relate to the immunisation of children is reflected in the fact that the percentage of children who receive standard vaccination has decreased in recent years. This may lead to the outbreak of various epidemics, including diseases which have already been eradicated. Such a phenomenon is in contrast with societal progression.

The value of the I-squared distance has been computed individually for each country and the obtained results are presented in Table 3.

Table 3 shows that Luxemburg is at the top of the list according to the I-distance method. The same result was obtained by Išljamović et al. [7] in the socio-economic research on the development of EU countries as well as Koster [35] who observed the economic openness and welfare of 67 countries from different regions of the world. Koster singled Luxemburg out as a country that should be a role model. Luxembourg has achieved this position as a result of having the highest GDP per capita, the lowest Mortality rate and the highest Population growth in comparison to other EU countries. Bearing in mind the fact that these three indicators are most significant, this result is not surprising. Also, Luxembourg's position can be explained by the fact that it is a state which has been able to continually develop and improve its generous and extensive social welfare regime over the past 100 years [36]. Over the last two decades, governments have increased the standard of living of their respective populations by introducing a range of social benefits and support for the elderly and the disabled, parental leave, child care assistance, etc. On the other hand, Luxembourg, with its relatively small economy, is able to adapt quickly and define special laws that will attract a qualified labour force, foreign companies, etc. Luxembourg is followed by other Northern European countries: Sweden, Finland, the Netherlands and Denmark. A similar result was observed in the studies of Išljamović et al. [7] and Radojičić et al. [6]. In these two papers, Sweden is ranked at third and at first place, respectively. The Netherlands is ranked as fourth and Denmark is ranked both at seventh and second place in their studies. These results are not surprising because many studies have been conducted over recent years and authors are discovering why Scandinavian countries are faring so well with regard to their welfare. The term the Scandinavian welfare model has become commonplace within the literature and this term refers to three basic factors: stateness, universalism, and equality [37]. Stateness involves a direct and positive connection between the state and its citizens. The influence of intermediary structures such as nongovernmental organisations is weak. Universalism includes universal social rights for all classes of society, social services and cash benefits that are available not only to the poorer classes but to the middle classes as well. Finally, equality involves relatively small 
differences between social classes, there are slight differences in income and gender differences are less pronounced than in other countries, while the female employment rate is high. The success of Scandinavian countries can be attributed to the lessons learned from the severe crisis which lasted from the 1980s to the 1990s. After which, these countries modernised their economic systems, making them more flexible [38]. The countries that have recently joined the European Union, such as Romania, Bulgaria, Lithuania, Latvia, Croatia, and Hungary, have ranked at the bottom of the list. The same results were observed in the paper written by Išljamović et al. [7].

Table 3. The results of the I-squared distance method for CSD indicators.

\begin{tabular}{ccc}
\hline Country & I-squared Distance & Rank \\
\hline Luxembourg & 95.32 & 1 \\
Sweden & 70.44 & 2 \\
Finland & 62.35 & 3 \\
Netherlands & 51.94 & 4 \\
Denmark & 51.24 & 5 \\
France & 47.57 & 6 \\
Germany & 47.37 & 7 \\
Slovenia & 45.77 & 8 \\
Austria & 44.55 & 9 \\
United Kingdom & 44.42 & 10 \\
Czech Republic & 43.43 & 11 \\
Belgium & 43.05 & 12 \\
Cyprus & 42.36 & 13 \\
Malta & 40.81 & 14 \\
Ireland & 40.54 & 15 \\
Italy & 37.37 & 16 \\
Spain & 36.58 & 17 \\
Estonia & 36.49 & 18 \\
Portugal & 35.30 & 19 \\
Slovak Republic & 33.45 & 20 \\
Greece & 33.23 & 21 \\
Poland & 28.74 & 22 \\
Hungary & 28.39 & 23 \\
Croatia & 26.94 & 24 \\
Latvia & 21.82 & 25 \\
Lithuania & 20.29 & 26 \\
Bulgaria & 17.42 & 27 \\
Romania & 14.84 & 28 \\
\hline
\end{tabular}

Source: Authors' own work.

\section{Conclusions}

The I-distance method has its advantages and disadvantages, as does every other method. The main advantage of this method is that it enables one to rank the observed units on the basis of a large number of indicators whose values are given per unit. Additionally, this method easily overcomes the problem of subjectively chosen weighting factors. Furthermore, it allows for the determination of the volume of information that each indicator provides, in order to set the position of a certain unit in comparison with another. One of the drawbacks of this method is that it is not internationally widespread, so there are insufficient references available, though it does not lag behind other ranking methods in quality [39]. Although recently, an important step has been taken to popularise this method beyond the borders of the region in which it arises. It is our sincere hope that our attempt to popularise this method will prove to be successful. The I-distance method has wide practical applications and has proved to be accurate in ranking observed units, which was shown in the research conducted by Jeremić et al. [10], when ranking the world's universities. 
The I-distance method has primarily singled out CSD indicators that significantly determine to what level the goals of sustainable development have been achieved and then commits the ranking of these indicators according to their importance and the amount of information they provide for a specific study. The GDP per capita stands out as the most significant of all indicators. This result is not surprising because the role of this indicator is always important with regard to socio-economic development and the welfare of a country. Additionally, the second most significant result is the Mortality rate (under five years of age), a social indicator, which describes the public health and the status of the health care system of a country.

The I-distance method has singled out EU countries that have achieved better results in implementing the sustainable development strategy and thus have achieved good results, such as Luxembourg which took first place, followed by other Northern European countries, i.e., Sweden, Finland, the Netherlands and Denmark. Moreover, they have distinguished countries that have been less successful at achieving their goals relating to sustainable development, and are therefore ranked at the bottom of the list. For the most part, these are countries that have recently joined the European Union, such as Romania, Bulgaria, Lithuania, Latvia, Croatia and Hungary. From the obtained results of the analyses, it can be concluded that the states should follow the example of Luxembourg or other Scandinavian countries, to take the steps necessary in terms of improving their social systems, which may potentially lead to an increase in the standard of living of their populations. In turn, this would increase the general welfare of the state.

In anticipation of the new set of indicators, which will measure to what level sustainable development goals are achieved, and which must first be approved by the United Nations, it is our hope that we have made a contribution with this research. In the very least, it has been our intention to look back on the previous work of such an important organisation in the field of sustainable development, a field that is of global significance.

Acknowledgments: This work was supported by the Ministry of Science and Technological Development: "Rural Labour Market and the Rural Economy of Serbia-Income Diversification as a Toll to Overcome Rural Poverty".

Author Contributions: Svjetlana Janković Šoja has collected, processed and interpreted data, and has written the manuscript. Ana Anokić and Dana Bucalo Jelić assisted in data interpretation, manuscript evaluation, and editing. Radojka Maletić supervised the development of the work and assisted in data interpretation.

Conflicts of Interest: The authors declare no conflict of interest.

\section{Abbreviations}

The following abbreviations are used in this manuscript:

CSD Commission on Sustainable Development

EU European Union

MENA Middle East and North Africa

OECD The Organisation for Economic Co-operation and Development

\section{References}

1. Brundtland, G.; Khalid, M.; Agnelli, S.; Al-Athel, S.; Chidzero, B.; Fadika, L.; Hauff, V.; Lang, V.; Lang, I.; Shijun, M.; et al. WCED-World Commission on Environment and Development. In Our Common Future; Oxford University Press: Oxford, UK, 1987; Available online: http://www.un-documents.net/ our-common-future.pdf (accessed on 20 February 2016).

2. United Nations Sustainable Development. United Nations Conference on Environment \& Development, Agenda 21, Rio de Janerio, Brazil, 3-14 June 1992. Available online: https:/ /sustainabledevelopment.un.org/ content/documents/Agenda21.pdf (accessed on 24 March 2016).

3. Department of Economic and Social Affairs. Indicators of Sustainable Development: Guidelines and Methodologies, 3rd ed.; United Nations: New York, NY, USA, 2007. 
4. United Nations. Resolution adopted by the General Assembly on 21 December 2012-Implementation of Agenda 21, the Programme for the Further Implementation of Agenda 21 and the outcomes of the World Summit on Sustainable Development and of the United Nations Conference on Sustainable Development. 27 February 2013. Available online: http://www.un.org/ga/search/ view_doc.asp?symbol=A/RES/67/203\&Lang=E (accessed on 21 February 2016).

5. United Nations, Commission on Sustainable Development. Report on the Twentieth Session (13 May 2011 and 20 September 2013); United Nations: New York, NY, USA, 2013; Available online: http:// www.un.org/ga/search/view_doc.asp?symbol=E/CN.17/2013/4\&Lang=E (accessed on 21 February 2016).

6. Radojičić, Z.; Išljamović, S.; Petrović, N.; Jeremić, V. A novel approach to evaluating sustainable development. Probl. Ekorozw.-Probl. Sustain. Dev. 2012, 7, 81-85.

7. Išljamović, S.; Jeremić, V.; Petrović, N.; Radojičić, Z. Colouring the socio-economic development into green: I-distance framework for counties' welfare evaluation. Qual. Quant. 2015, 49, 617-629. [CrossRef]

8. Milenkovic, N.; Vukmirovic, J.; Bulajic, M.; Radojicic, Z. A multivariate approach in measuring socio-economic development of MENA countries. Econ. Model. 2014, 38, 604-608. [CrossRef]

9. Jeremić, V.; Seke, K.; Radojičić, Z.; Jeremić, D.; Marković, A.; Slović, D.; Aleksić, A. Measuring health of countries: A novel approach. Health MED 2011, 5, 1762-1766.

10. Jeremić, V.; Bulajić, M.; Martić, M. A fresh approach to evaluating the academic ranking of world universities. Scientometrics 2011, 87, 587-596. [CrossRef]

11. Popović, B.; Maletić, R. Grouping of municipalities of the Republic of Serbia based on development of small and medium agribusiness. Economics of Agriculture, 2008, pp. 151-161. Available online: http:/ / www.ea.bg.ac.rs/images / Arhiva/2008/Broj\%202\%20-\%202008\%20=\%20Issue \%202\%20-\%202008.pdf (accessed on 24 March 2016).

12. Maletić, R.; Popović, B. Ranking of Vojvodina municipalities based on efficiency of SMEs in agribusiness. Agroekonomika 2014, 43, 39-49.

13. Maletić, R.; Popović, B. A Ranking of Serbian Districts Based on the Efficiency of SMEs in Agribusiness. Proceedings of the "Agriculture and Rural Development-Challenges of Transition and Integration Processes", Belgrade, Serbia, September; Department of Agricultural Economics, Faculty of Agriculture, University of Belgrade: Belgrade, Serbia, 2013; pp. 151-163.

14. Halog, A.; Manik, Y. Advancing integrated systems modelling framework for life cycle sustainability assessment. Sustainability 2011, 3, 469-499. [CrossRef]

15. Kudoh, Y.; Sagisaka, M.; Chen, S.S.; Elauria, J.C.; Gheewala, S.H.; Hasanudin, U.; Romero, J.; Sharma, V.D.; Shi, X. Region-Specific Indicators for Assessing the Sustainability of Biomass Utilisation in East Asia. Sustainability 2015, 7, 16237-16259. [CrossRef]

16. Santiago-Brown, I.; Metcalfe, A.; Jerram, C.; Collins, C. Sustainability Assessment in Wine-Grape Growing in the New World: Economic, Environmental, and Social Indicators for Agricultural Businesses. Sustainability 2015, 7, 8178-8204. [CrossRef]

17. OECD. OECD Environmental Outlook to 2030; OECD Publishing: Paris, France, 2008; Available online: http://www.keepeek.com/Digital-Asset-Management/oecd/environment/oecd-environmental-outlook-to2030_9789264040519-en\#page1 (accessed on 8 March 2016).

18. OECD. OECD Environmental Outlook to 2050; OECD Publishing: Paris, France, 2012; Available online: http:/ /dx.doi.org/10.1787/9789264122246-en (accessed on 9 March 2016).

19. World Bank Data. Available online: http://data.worldbank.org/ (accessed on 21 November 2015).

20. Eurostat. Available online: http:/ / ec.europa.eu/eurostat/data/database (accessed on 22 November 2015).

21. Ivanović, B. Discriminant Analysis; Science Books: Belgrade, Serbia, 1963.

22. Ivanović, B. A Method of Establishing a List of Development Indicators; United Nations Educational, Scientific and Cultural Organization: Paris, France, 1973.

23. Ivanović, B.; Fanchette, S. Grouping and Ranking of 30 Countries of Sub-Saharan Africa, Two Distance-based Methods Compared; United Nations Educational, Scientific and Cultural Organization: Paris, France, 1973.

24. Ivanović, B. Classification Theory; Institute for Industrial Economic: Belgrade, Serbia, 1977.

25. Jeremić, V.; Išljamović, S.; Petrovic, N.; Radojičić, Z.; Marković, A.; Bulajić, M. Human development index and sustainability: What's the correlation? Metal. Int. 2011, 16, 63-67.

26. Campisi, D.; de Nicola, A.; Farhadi, M.; Mancuso, P. Discovering the impact of ICT, FDI and human capital on GDP: A cross-sectional analysis. Int. J. Eng. Bus. Manag. 2013, 5, 1-10. [CrossRef] 
27. Espina, P.Z.; Arechavala, N.S. An assessment of social welfare in Spain: Territorial analysis using a synthetic welfare indicator. Soc. Indic. Res. 2013, 111, 1-23. [CrossRef]

28. Mahdavi, S.; Alanis, E. Public expenditures and the unemployment rate in the American states: Panel evidence. Appl. Econ. 2013, 45, 2926-2937. [CrossRef]

29. Markusen, J. Putting per-capita income back into trade theory. J. Int. Econ. 2013, 90, 255-265. [CrossRef]

30. Davidson, E.A. You can't Eat GNP: Economics as if Ecology Mattered; Perseus: Cambridge, UK, 2000.

31. Cracolici, M.F.; Cuffaro, M.; Nijkamp, P. The Measurement of Economic, Social and Environmental Performance of Countries: A Novel Approach. Soc Indic Res. 2010, 95, 339-356. [CrossRef] [PubMed]

32. Nolte, E.; McKee, C.M. Measuringthe health of nations: Updating an earlier analysis. Health Aff. 2008, 27, 58-71. [CrossRef] [PubMed]

33. Chew, H.E.; Ilavarasan, P.V.; Levy, M.R. The Economic Impact of information and communication technologies (ICTs) on microenterprises in the context of development. EJISDC 2010, 44, 1-19.

34. Miranda, L.C.M.; Lima, C.A.S. Trends and cycles of the internet evolution and worldwide impacts. Technol. Forecast. Soc. Change 2012, 79, 744-765. [CrossRef]

35. Koster, F. Economic openness and welfare state attitudes: A multilevel study across 67 countries. Int. J. Soc. Welf. 2013, 21, 115-126. [CrossRef]

36. Hartmann-Hirsch, C. The State of the Luxembourg's Welfare State: The Effects of the Crisis on a Corporatist Model Shifting to a Universalistic Model. CEPS/INSTEAD Working Papers. 2010. Available online: http:/ / www.statistiques.public.lu/catalogue-publications/working-papers-CEPS/2010/44-2010.pdf (accessed on 24 March 2016).

37. Alestalo, M.; Hort, S.E.O.; Kuhnle, S. The Nordic Model: Conditions, Origins, Outcomes, Lessons. Hertie School Governance Working Paper No. 41. 2009. Available online: https://www.hertie-school.org/ fileadmin/images/Downloads/working_papers/41.pdf (accessed on 25 February 2016).

38. Nordic Centre for Welfare and Social Issues. Focus on the Nordic Welfare Model. 2013. Available online: http://www.nordicwelfare.org/PageFiles/7117/Nordic_Welfare_Model_Web.pdf (accessed on 25 February 2016).

39. Maletić, R.; Maletić, P.; Kreca, M.; Popović, B. Comparative analysis of ranking municipalities in Vojvodina using DEA and I-distance methods. Int. J. Agric. Stat. Sci. 2013, 9, 471-480.

(C) 2016 by the authors; licensee MDPI, Basel, Switzerland. This article is an open access article distributed under the terms and conditions of the Creative Commons by Attribution (CC-BY) license (http://creativecommons.org/licenses/by/4.0/). 